\title{
Stable Isotope and Hydrochemical Evolution of Groundwater in Mining Area of the Changzhi Basin, Northern China
}

Chunchao Zhang ( $\sim$ ihegzcc@163.com )

Institute of Hydrogeology and Environmental Geology

Xiangquan Li

Institute of Hydrogeology and Environmental Geology

Jianfei Ma

Institute of Hydrogeology and Environmental Geology

Zhenxing Wang

Institute of Hydrogeology and Environmental Geology

Xinwei Hou

Institute of Hydrogeology and Environmental Geology

\section{Research Article}

Keywords: Groundwater, Hydrogeochemistry, Stable isotopes, Hydrochemical mechanisms, Anthropogenic activities, Coal mining

Posted Date: November 1st, 2021

DOI: https://doi.org/10.21203/rs.3.rs-823775/v1

License: (c) (7) This work is licensed under a Creative Commons Attribution 4.0 International License. Read Full License 


\section{Abstract}

The Changzhi Basin of China is an economically and ecologically important area with intensive human activities. To foster the sustainable development of groundwater resources and the economy, a total of 117 groundwater samples were collected in shallow and deep aquifers, including $91^{2} \mathrm{H}$ and ${ }^{18} \mathrm{O}$ isotope samples, to improved understanding of the natural geochemical processes and the impacts of anthropogenic activities on the groundwater chemistry. Synthetical application of the stable isotopes, Piper diagram, Gibbs diagram, ionic ratios and saturation indices to data analysis led to identification of hydrochemical zones for both aquifers from west to east of the basin. Isotopic analyses suggested that the groundwater recharge mainly comes from infiltration of rain water, hydraulic interaction between surface water and shallow groundwater, and lateral recharge from fissure water at the edge of the basin. The predominant natural geochemical processes include mineral dissolution in conjunction with the cation exchange. The excess deuterium method revealed that mineral dissolution contributed $81 \%-98 \%$ to the salinity of shallow groundwater and $84 \%-98 \%$ to the salinity of deep groundwater. Anthropogenic activities are secondary contributions to the hydrochemical evolution with fertilizer application, human waste and sewage discharges causing an increase in $\mathrm{NO}_{3}{ }^{-} \mathrm{N}$ content and coal mining activities affecting the ion content of $\mathrm{Na}^{+}, \mathrm{Cl}^{-}, \mathrm{SO}_{4}{ }^{2-}$, and $\mathrm{HCO}_{3}{ }^{-}$in the groundwater.

\section{Introduction}

Groundwater resources are increasingly exploited for industrial and agricultural purposes in many arid and semi-arid regions globally (Li et al., 2019; Liu et al., 2015). In the last few decades, rapid developments in industry, agriculture, and coal mining, together with rapid urban population growth, has led to dramatic changes in water chemistry in many developing countries (Jamshidzadeh and Mirbagheri, 2011; Sandow et.al, 2010). Water chemistry can be used to facilitate an understanding of the natural geochemical processes and the effects of anthropogenic activities (Liu et al., 2015; Selvakumar et al., 2017). The study of hydrochemical processes and the factors affecting water quality provides an insight to the controlling mechanisms of groundwater hydrochemistry, and is important for sustainable development and effective protection of groundwater (Tizro and Voudouris, 2008; Chang and Wang, 2010; Yang et al., 2016; Mohanty et al., 2019).

The combination of hydrogeochemical methods such as the Piper diagram, Gibbs diagram, ionic ratios, and multiple isotopic analyses have been widely used to study hydrochemical evolution (Plummer et al., 1990; Marfia et al., 2004; Wang et al., 2006; Qian et al., 2013; Liu et al., 2015; Sánchez et al., 2015). Isotopic and geochemical indicators often serve as effective methods for solving multiple problems in hydrology and hydrogeology, especially in semi-arid and arid regions (Clark and Fritz, 1997; Zang et al., 2018). Stable isotopes of $\mathrm{H}$ and $\mathrm{O}$ are typical tracers for investigating the sources of groundwater recharge and the hydrological cycle because the stable isotopes are constituents of the water molecules (Chen et al., 2012; Jia et al., 2017). Hydrogeochemical indicators in different water bodies can provide information on the geochemical reactions within the aquifer and on the possible evolutionary pathways of groundwater (Cook and Herczeg, 1999; Appelo and Postma, 2004).

The Changzhi Basin is located in the arid to semi-arid area of northern China. Because of population growth and the increasing development of agricultural and coal mining activities, the demand for groundwater is continually increasing. Groundwater pollution in the Changzhi Basin is, however, increasing as a result of the large-scale and long-term discharge of coal mining water, domestic sewage, and industrial waste water, and the excessive use of fertilizers. Various studies on karst groundwater in the Changzhi Basin have been conducted, and were mainly focused on karst spring flow, groundwater quality, and water resource protection (Sun, 2008; Chen et al., 2012; Yang et al., 2016). Studies on groundwater hydrochemistry and evolution processes in the porous media are lacking. The present study addresses this knowledge gap. To obtain a comprehensive understanding of the evolution of groundwater hydrochemistry in the Changzhi Basin, it is necessary to identify the impacts of natural factors and anthropogenic activities on the groundwater hydrochemistry. Consequently, the main objectives of the present study are to: (1) interpret the hydrochemical and stable isotopic characteristics; (2) ascertain the origin of groundwater and reveal the hydrochemical formation mechanisms for both natural geochemical processes and anthropogenic activities; and (3) quantify the contribution of mineral dissolution, evaporation, and cation exchange factors in controlling the chemical composition of groundwater.

\section{Regional Hydrogeology}

The Changzhi Basin is located in the southeast of Shanxi Province (Fig. 1), encompassing an area of $1,169 \mathrm{~km}^{2}$, and lying between $36^{\circ} 00^{\prime}$ and $36^{\circ} 19^{\prime} \mathrm{N}$ and $112^{\circ} 46^{\prime}$ and $113^{\circ} 16^{\prime} \mathrm{E}$. The annual mean air temperature of the study area ranged from 8.9 to $10.9^{\circ} \mathrm{C}$ over the past 30 years. The average rainfall from 1956 to 2018 was $536 \mathrm{~mm}$, with a range from $264 \mathrm{~mm}$ (1965) to 1,056 mm (1971). 60-70\% of the annual rainfall was concentrated in July, August, and September. The annual mean water surface evaporation was $1,678 \mathrm{~mm}$, with a maximum of 1,810 mm and a minimum of 1,372 mm. The Zhuozhang River, the main river in the basin, runs from the south to the north. The main tributaries of the Zhuozhang River are the Taoqing, Lanshui, Jianghe, and Yuni Rivers. The Zhangze Reservoir is the only large-scale reservoir in the study area, while there are many medium and small-sized reservoirs, such as the Baojiahe, Tunjiang, and Shencun Reservoirs.

Geologically, Changzhi Basin is a Cenozoic fault basin. The main outcropping strata in the study area are of Quaternary (Q) age. Permian (P), Carboniferous (C), and Ordovician (0) strata outcrop locally. The Quaternary sediments are 0-300 m thick, and the sediments thicken from west to east (Fig. 2). The main aquifers are in the unconsolidated sediments, and divided into shallow ( $\leq 50 \mathrm{~m}$ in depth) and deep (>50 $\mathrm{m}$ in depth) aquifers. The shallow aquifer is unconfined in alluvial-proluvial sand-gravel layers of the Holocene and Upper Pleistocene. The deep aquifer is confined in silt, sand, and gravel lenses of the Middle and Lower Pleistocene. The unconfined and confined aquifers are separated by a discontinuous aquitard composed of a mudstone layer. The regional groundwater flows towards the Zhangze Reservoir and Zhuozhang River (i.e., from the west, east, and south).

\section{Sampling And Analysis}


A total of 117 groundwater samples were collected in April and November, 2018. The samples comprised 76 shallow groundwater samples, 36 deep groundwater samples, and 5 mine drainage samples. The sampling locations are shown in Fig. 1. Mine drainage samples were taken from the water drained from the mines to enable the exploitation of coal-bed methane and coal. Additionally, 24 rainwater samples were collected from central, eastern, and western areas of the basin from July, 2017 to July, 2018 for stable isotope tests; whereas, three of these samples were also used for hydrochemical tests. The samples were filtered through $0.45 \mu \mathrm{m}$ membranes on site and then stored at $4^{\circ} \mathrm{C}$. The bottles were rinsed twice with deionized water before sampling. For cation analysis, water samples were acidified using analytically pure nitric acid to $\mathrm{pH}<2$. Samples for stable isotope analysis $\left(\delta^{18} \mathrm{O}\right.$ and $\left.\delta^{2} \mathrm{H}\right) \mathrm{were}$ collected in $50 \mathrm{~mL}$ glass bottles, which were sealed with airtight caps.

\subsection{Measurement methods}

Water temperature, $\mathrm{pH}$, and electrical conductivity were directly measured on-site using a HANNA HI 991301 multi-parameter instrument. Major anions, cations and minor elements were analyzed by a Thermo Scientific Dionex ICS-4000 (precision $= \pm 1 \%$ ) and PerkinElmer Optima 8300 inductively coupled plasmaoptical emission spectrometer (precision $= \pm 1 \%$ ) at the Groundwater Mineral Water and Environmental Monitoring Center in the Institute of Hydrogeology and Environmental Geology at the Chinese Academy of Geological Sciences. The analytical precision and electrical balance error of the hydrochemical data were within $\pm 5 \%$.

Stable isotope ratios were expressed in $\delta(\%)$ notation and calculated with respect to Vienna Standard Mean Ocean Water (VSMOW). The $\delta^{18} \mathrm{O}$ and $\delta \mathrm{D}$ values in water samples were obtained using a Picarro L2130-i Analyzer at the Institute of Hydrogeology and Environmental Geology at the Chinese Academy of Geological Sciences. The analytical precision for $\delta D$ was $\pm 1 \%$ ond for $\delta^{18} 0$ was $\pm 0.1 \%$.

\section{Results And Discussion}

\subsection{Hydrochemical characteristics}

The physicochemical parameters of the water samples are shown in Table 1; all water sample data were plotted on Piper diagrams (Fig. 3a-c). A coefficient of variation (Cv) is commonly used to characterize the stability of a variable: $0<\mathrm{Cv}<0.1$ indicates weak variability; $0.1<\mathrm{Cv}<1.0$ indicates moderate variability; and $\mathrm{Cv}>1.0$ indicates wide variability (Yang et al., 2016; Zhai et al., 2019).

\subsubsection{Rain water, surface water, and mine drainage}

The $\mathrm{pH}$ values of rain water ranged from 6.39 to 6.63 , indicating weakly acidic conditions. Surface water ( $\mathrm{pH} 7.03-7.94)$ and mine drainage ( $\mathrm{pH} 7.85-8.90)$ were generally neutral to weakly alkaline. The concentrations of the chemical components in rain water were, in general, low. Most of the chemical components in surface water and rain water exhibited a weak to medium variability, but a wide variability in mine drainage. The maximum concentrations of total dissolved solids (TDS), $\mathrm{Na}^{+}, \mathrm{Cl}^{-}$, and $\mathrm{SO}_{4}{ }^{2-}$ for mine drainage were $2,901,1,176,1,078$, and $1,218 \mathrm{mg} \cdot \mathrm{L}^{-1}$, respectively, and were significantly greater than the maximum concentrations for surface water and rain water.

The chemical components of surface water were dominated by $\mathrm{Ca}^{2+}, \mathrm{Na}^{+}, \mathrm{HCO}_{3}{ }^{-}, \mathrm{SO}_{4}{ }^{2-}$, and $\mathrm{Cl}^{-}$, and the hydrochemical types were complex. The $\mathrm{HCO}_{3} \cdot \mathrm{SO}_{4}{ }^{-}$ $\mathrm{Ca} \cdot \mathrm{Mg}, \mathrm{HCO}_{3} \cdot \mathrm{Cl} \cdot \mathrm{SO}_{4}-\mathrm{Ca} \cdot \mathrm{Na}, \mathrm{HCO}_{3}-\mathrm{Ca} \cdot \mathrm{Na}, \mathrm{SO}_{4} \cdot \mathrm{Cl}-\mathrm{Na} \cdot \mathrm{Ca}$, and $\mathrm{HCO}_{3} \cdot \mathrm{Cl}-\mathrm{Ca}$ types were all identified for surface water. The chemical components of mine drainage were dominated by $\mathrm{Na}^{+}, \mathrm{HCO}_{3}{ }^{-}, \mathrm{SO}_{4}{ }^{2-}$, and $\mathrm{Cl}^{-}$, and hydrochemical types were mainly $\mathrm{HCO}_{3} \cdot \mathrm{Cl}-\mathrm{Na}$ and $\mathrm{SO}_{4}{ }^{-} \mathrm{Na}$. The chemical components of rain water were, however, dominated by $\mathrm{Ca}^{2+}, \mathrm{HCO}_{3}{ }^{-}$, and $\mathrm{SO}_{4}{ }^{2-}$, and the hydrochemical type was $\mathrm{HCO}_{3} \cdot \mathrm{SO}_{4}-\mathrm{Ca}$.

\subsubsection{Groundwater}

The $\mathrm{pH}$ values of the shallow groundwater ranged from 7.13 to 8.07 , and had a mean value of 7.53 , which indicates near neutral to weakly alkaline conditions. Total hardness $(\mathrm{TH})$ and TDS of the shallow groundwater varied from 168.1 to $1,889 \mathrm{mg} \cdot \mathrm{L}^{-1}$ and from 208.8 to $2,559 \mathrm{mg} \cdot \mathrm{L}^{-1}$, respectively. The chemical components were dominated by $\mathrm{Ca}^{2+}, \mathrm{HCO}_{3}{ }^{-}, \mathrm{SO}_{4}{ }^{2-}$, and $\mathrm{Cl}^{-}$. Of the shallow groundwater samples, $51 \%$ were of the $\mathrm{HCO}_{3}-\mathrm{Ca}$ type and had a low TDS (mean value $=409.6 \mathrm{mg} \cdot \mathrm{L}^{-1}$ ); $16 \%$ were of the $\mathrm{HCO}_{3} \cdot \mathrm{SO}_{4}-\mathrm{Ca} / \mathrm{Mg}$ type and had a medium TDS (mean value $=647.6 \mathrm{mg} \cdot \mathrm{L}^{-1}$ ); and $13 \%$ were of the $\mathrm{SO}_{4} \cdot \mathrm{HCO}_{3}\left(\mathrm{SO}_{4} \cdot \mathrm{HCO}_{3} \cdot \mathrm{Cl}\right.$ )-Ca/Mg type and had a high ion content (mean value $=1,412.5 \mathrm{mg} \cdot \mathrm{L}^{-1}$ ). Moreover, the $\mathrm{SO}_{4} \cdot \mathrm{Cl}-\mathrm{Ca}, \mathrm{Cl} \cdot \mathrm{SO}_{4}-\mathrm{Ca}$, and $\mathrm{HCO} \cdot \mathrm{Cl}-\mathrm{Ca}$ type was also identified for shallow groundwater (Fig. 3b). The $\mathrm{Cv}$ values of $\mathrm{K}^{+}, \mathrm{Cl}^{-}, \mathrm{SO}_{4}{ }^{2-}$, and $\mathrm{NO}_{3}{ }^{-}$were greater than 1.0, which indicates that these hydrochemical components had a wide variation in spatial distribution. The TDS content gradually increased (from 208.8 to $2,559 \mathrm{mg} \cdot \mathrm{L}^{-1}$ ) from the west to the east of the basin. In the west of the basin, the chemical type was mainly $\mathrm{HCO}_{3}-\mathrm{Ca}$. However, in the east of the basin, the chemical types were $\mathrm{complex} \mathrm{SO}_{4} \cdot \mathrm{HCO}{ }_{3}-\mathrm{Ca} / \mathrm{Mg}_{\text {, }}$ $\mathrm{SO}_{4} \cdot \mathrm{Cl}-\mathrm{Ca}, \mathrm{Cl} \cdot \mathrm{SO}_{4}-\mathrm{Ca}$, and $\mathrm{HCO}_{3} \cdot \mathrm{Cl}-\mathrm{Ca}$ were all identified and the TDS values were high $\left(780-2,559 \mathrm{mg} \cdot \mathrm{L}^{-1}\right)$.

For deep groundwater, the $\mathrm{pH}$ values ranged from 7.04 to 7.97 , with a mean value of 7.57 , indicating near neutral to weakly alkaline conditions. The TH and TDS of the deep groundwater varied from 177.1 to $1,559 \mathrm{mg} \cdot \mathrm{L}^{-1}$ and from 240.2 to $2,160 \mathrm{mg} \cdot \mathrm{L}^{-1}$, respectively. The chemical components were dominated by $\mathrm{Ca}^{2+}, \mathrm{Mg}^{2+}, \mathrm{HCO}_{3}{ }^{-}$, and $\mathrm{SO}_{4}{ }^{2-}$. Of the deep groundwater samples, $61 \%$ were of the $\mathrm{HCO}_{3}-\mathrm{Ca} / \mathrm{Mg}$ type and had a low TDS (mean values $=381.8 \mathrm{mg} \cdot \mathrm{L}^{-1}$ ); $17 \%$ were of the $\mathrm{HCO}_{3} \cdot \mathrm{SO}_{4}-\mathrm{Ca} / \mathrm{Mg}$ type and had a medium TDS (mean values $=653.45 \mathrm{mg} \cdot \mathrm{L}^{-1}$ ); and $8 \%$ were of the $\mathrm{SO}_{4} \cdot \mathrm{HCO}_{3}-\mathrm{Ca} / \mathrm{Mg}$ type and had a high ion content (mean values $=1,277.4 \mathrm{mg} \cdot \mathrm{L}^{-1}$ ). Moreover, the $\mathrm{HCO}_{3} \cdot \mathrm{SO}_{4} \cdot \mathrm{Cl}-\mathrm{Ca}$ and $\mathrm{HCO}_{3} \cdot \mathrm{Cl} \cdot \mathrm{SO}_{4}-\mathrm{Ca}$ types were also identified (Fig. $3 \mathrm{c}$ ). The $\mathrm{Cv}$ values of $\mathrm{Cl}^{-}$, $\mathrm{SO}_{4}{ }^{2-}$, and $\mathrm{NO}_{3}{ }^{-}$were greater than 1.0, indicating that these hydrochemical components had a wide variation in spatial distribution. The TDS of the deep groundwater gradually increased (from 240.2 to $2,160 \mathrm{mg} \cdot \mathrm{L}^{-1}$ ) from the west to the east of the basin. In the west and central of the basin, the groundwater is 
mainly of the $\mathrm{HCO}_{3}$-Ca type. However, in the east of the basin, as a result of low discharge and weak self-purification capacity, the $\mathrm{SO}_{4} \cdot \mathrm{HCO}-\mathrm{Ca} / \mathrm{Mg}_{3}$ $\mathrm{HCO}_{3} \cdot \mathrm{SO}_{4} \cdot \mathrm{Cl}-\mathrm{Ca}$, and $\mathrm{HCO}_{3} \cdot \mathrm{Cl} \cdot \mathrm{SO}_{4}$-Ca types were all identified for the deep groundwater, which had a high TDS of approximately $800-2,160 \mathrm{mg} \cdot \mathrm{L}^{-1}$.

The concentrations of minor and trace elements, such as $\mathrm{F}, \mathrm{Cr}$, As, Fe, Mn, and $\mathrm{Pb}$, were generally low, and most were not detected. In terms of the Groundwater Quality Standards of China (GB/T $14848-2017)$, values of $F, C r$, and As are all below the Chinese III quality standards $\left(1.0 \mathrm{mg} \cdot \mathrm{L}^{-1} \mathrm{for} F, 0.05 \mathrm{mg} \cdot \mathrm{L}^{-1} \mathrm{for} \mathrm{Cr}\right.$, and $0.01 \mathrm{mg} \cdot \mathrm{L}^{-1}$ for $\left.\mathrm{As}\right)$. The concentrations of $\mathrm{Fe}, \mathrm{Mn}$, and $\mathrm{Pb}$ exceed the III quality standards in some samples. The standards for $\mathrm{Fe}, \mathrm{Mn}$, and $\mathrm{Pb}\left(0.3 \mathrm{mg} \cdot \mathrm{L}^{-}\right.$ 1 for $\mathrm{Fe}, 0.10 \mathrm{mg} \cdot \mathrm{L}^{-1}$ for $\mathrm{Mn}$, and $0.01 \mathrm{mg} \cdot \mathrm{L}^{-1}$ for $\mathrm{Pb}$ ) were exceeded in samples 6,7 , and 6 , respectively. These samples were taken from shallow groundwater.

Table 1

Chemical properties and composition of groundwater, surface water, rain water, and mine drainage samples in the Changzhi Basin. $\mathrm{n}=\mathrm{number}$ of samples; ( variation; $\mathrm{TH}=$ total hardness; TDS = total dissolved solids. Units: $\mathrm{pH}$ in units of $\mathrm{pH}$, major ions and minor elements in $\mathrm{mg} \cdot \mathrm{L}^{-1}$

\begin{tabular}{|c|c|c|c|c|c|c|c|c|c|c|c|c|c|}
\hline & \multicolumn{3}{|c|}{$\begin{array}{l}\text { shallow groundwater }(n= \\
76)\end{array}$} & \multicolumn{3}{|c|}{ deep groundwater( $n=37)$} & \multicolumn{3}{|c|}{ surface water $(n=11)$} & \multicolumn{3}{|c|}{ rain water( $(n=3)$} & \multirow{2}{*}{$\begin{array}{l}\text { mine dre } \\
\text { range }\end{array}$} \\
\hline & range & average & $\mathrm{Cv}$ & range & average & $\mathrm{Cv}$ & range & Average & $\mathrm{Cv}$ & range & average & $\mathrm{Cv}$ & \\
\hline $\mathrm{pH}$ & $\begin{array}{l}7.13 \sim \\
8.07\end{array}$ & 7.53 & 0.02 & $\begin{array}{l}7.04 \sim \\
7.97\end{array}$ & 7.57 & 0.03 & $\begin{array}{l}7.03 \sim \\
7.94\end{array}$ & 7.42 & 0.04 & $\begin{array}{l}6.39 \sim \\
6.63\end{array}$ & 6.47 & 0.02 & $\begin{array}{l}7.85 \sim \\
8.9\end{array}$ \\
\hline Hardness & $\begin{array}{l}168.1 \\
\sim 1889\end{array}$ & 547.58 & 0.68 & $\begin{array}{l}177.1 \\
\sim 1559\end{array}$ & 386.17 & 0.66 & $\begin{array}{l}136.1 \\
\tilde{4} 17.3\end{array}$ & 267.03 & 0.38 & $\begin{array}{l}9.01 \sim \\
19.52\end{array}$ & 13.51 & 0.40 & $\begin{array}{l}14.01 \\
\tilde{3} 60.3\end{array}$ \\
\hline TDS & $\begin{array}{l}208.8 \\
\sim 2559\end{array}$ & 744.02 & 0.71 & $\begin{array}{l}240.2 \\
\sim 2160\end{array}$ & 510.86 & 0.69 & $\begin{array}{l}190.1 \\
\sim 955\end{array}$ & 511.47 & 0.51 & $\begin{array}{l}27.51 \\
\sim \\
48.41\end{array}$ & 34.84 & 0.34 & $\begin{array}{l}715 \sim \\
2901\end{array}$ \\
\hline $\mathrm{K}^{+}$ & $\begin{array}{l}0.06 \sim \\
30.08\end{array}$ & 1.25 & 3.01 & $\begin{array}{l}0.14 \sim \\
2.68\end{array}$ & 0.58 & 0.84 & $\begin{array}{l}1.6 \sim \\
17.83\end{array}$ & 7.08 & 0.86 & $\begin{array}{l}0.24 \sim \\
0.78\end{array}$ & 0.48 & 0.57 & $\begin{array}{l}1.63 \sim \\
22.72\end{array}$ \\
\hline $\mathrm{Na}^{+}$ & $\begin{array}{l}9.08 \sim \\
165.7\end{array}$ & 36.67 & 0.80 & $\begin{array}{l}8.9 \sim \\
73.72\end{array}$ & 24.62 & 0.64 & $\begin{array}{l}13.2 \sim \\
226.2\end{array}$ & 76.34 & 0.88 & $\begin{array}{l}0.39 \sim \\
1.24\end{array}$ & 0.75 & 0.59 & $\begin{array}{l}265.3 \\
\sim 1176\end{array}$ \\
\hline $\mathrm{Ca}^{2+}$ & $\begin{array}{l}56.06 \\
\sim \\
537.5\end{array}$ & 159.87 & 0.66 & $\begin{array}{l}50.66 \\
\sim \\
476.1\end{array}$ & 113.65 & 0.69 & $\begin{array}{l}27.56 \\
\tilde{115.8}\end{array}$ & 67.62 & 0.45 & $\begin{array}{l}3.24 \sim \\
6.58\end{array}$ & 4.71 & 0.36 & $\begin{array}{l}3.97 \sim \\
73.3\end{array}$ \\
\hline $\mathrm{Mg}^{2+}$ & $\begin{array}{l}6.78 \sim \\
151.2\end{array}$ & 36.04 & 0.77 & $\begin{array}{l}8.83 \sim \\
89.86\end{array}$ & 24.87 & 0.65 & $\begin{array}{l}15.78 \\
\tilde{4} 0.82\end{array}$ & 23.84 & 0.35 & $\begin{array}{l}0.24 \sim \\
0.71\end{array}$ & 0.40 & 0.66 & $\begin{array}{l}0.98 \sim \\
42.99\end{array}$ \\
\hline $\mathrm{Cl}^{-}$ & $\begin{array}{l}7.72 \sim \\
548\end{array}$ & 90.28 & 1.26 & $\begin{array}{l}5.26 \sim \\
311\end{array}$ & 40.11 & 1.35 & $\begin{array}{l}13.51 \\
\tilde{1} \\
196.1\end{array}$ & 80.37 & 0.70 & $\begin{array}{l}1.40 \sim \\
2.45\end{array}$ & 1.87 & 0.29 & $\begin{array}{l}76.42 \\
\sim 1078\end{array}$ \\
\hline $\mathrm{SO}_{4}{ }^{2-}$ & $\begin{array}{l}5.38 \sim \\
720.7\end{array}$ & 144.64 & 1.09 & $\begin{array}{l}6.61 \sim \\
469.1\end{array}$ & 90.53 & 1.16 & $\begin{array}{l}48.84 \\
\tilde{3} 14.5\end{array}$ & 127.66 & 0.76 & $\begin{array}{l}6.27 \sim \\
11.97\end{array}$ & 8.64 & 0.34 & $\begin{array}{l}2.17 \sim \\
1218\end{array}$ \\
\hline $\mathrm{HCO}_{3}{ }^{-}$ & $\begin{array}{l}157.1 \\
\tilde{5} 81.1\end{array}$ & 305.79 & 0.29 & $\begin{array}{l}197.3 \\
\tilde{4} 82.8\end{array}$ & 272.07 & 0.27 & $\begin{array}{l}94.07 \\
\sim 290\end{array}$ & 209.70 & 0.33 & $\begin{array}{l}11.72 \\
\tilde{2} \\
24.16\end{array}$ & 16.85 & 0.39 & $\begin{array}{l}363.7 \\
\tilde{9} \\
941.8\end{array}$ \\
\hline $\mathrm{NO}_{3}{ }^{-}$ & $\begin{array}{l}1.84 \sim \\
873.4\end{array}$ & 102.83 & 1.37 & $\begin{array}{l}8.39 \sim \\
580.9\end{array}$ & 61.59 & 1.65 & $\begin{array}{l}0.2 \sim \\
86.66\end{array}$ & 15.42 & 1.72 & $\begin{array}{l}3.61 \sim \\
6.51\end{array}$ & 5.41 & 0.29 & $\begin{array}{l}1.9 \sim \\
6.67\end{array}$ \\
\hline $\mathrm{F}^{-}$ & $\begin{array}{l}0.29 \sim \\
0.78\end{array}$ & 0.47 & 0.21 & $\begin{array}{l}0.23 \sim \\
0.59\end{array}$ & 0.44 & 0.19 & $\begin{array}{l}0.31 \sim \\
2.02\end{array}$ & 0.71 & 0.74 & $\begin{array}{l}0.21 \sim \\
0.26\end{array}$ & 0.24 & 0.11 & $\begin{array}{l}1.86 \sim \\
7.74\end{array}$ \\
\hline $\mathrm{Cr}^{6+}$ & $\begin{array}{l}<0.004 \\
\sim 0.01\end{array}$ & - & - & $\begin{array}{l}<0.004 \\
\tilde{0} .028\end{array}$ & - & - & $<0.004$ & - & - & $<0.004$ & - & - & $<0.004$ \\
\hline As & $\begin{array}{l}<0.001 \\
\tilde{0} .037\end{array}$ & - & - & $<0.001$ & - & - & $\begin{array}{l}<0.001 \\
\tilde{0} \\
0.004\end{array}$ & - & - & $<0.001$ & - & - & $\begin{array}{l}<0.001 \\
\tilde{0} .032\end{array}$ \\
\hline $\mathrm{Fe}$ & $\begin{array}{l}<0.01 \\
\tilde{0} \\
0.058\end{array}$ & - & - & $\begin{array}{l}<0.01 \\
\tilde{1} \\
1.497\end{array}$ & - & - & $\begin{array}{l}<0.01 \\
\tilde{0} \\
0.599\end{array}$ & - & - & $<0.01$ & - & - & $\begin{array}{l}<0.01 \\
\sim 0.09\end{array}$ \\
\hline $\mathrm{Mn}$ & $\begin{array}{l}<0.001 \\
\tilde{2} .331\end{array}$ & - & - & $\begin{array}{l}<0.001 \\
\sim 0.17\end{array}$ & - & - & $\begin{array}{l}<0.001 \\
\tilde{0} \\
0.134\end{array}$ & - & - & $<0.001$ & - & - & $\begin{array}{l}<0.001 \\
\tilde{0} \\
0.293\end{array}$ \\
\hline $\mathrm{Pb}$ & $\begin{array}{l}<0.001 \\
\tilde{0} .269\end{array}$ & - & - & $\begin{array}{l}<0.001 \\
\tilde{0} .125\end{array}$ & - & - & $\begin{array}{l}<0.001 \\
\tilde{0} \\
0.058\end{array}$ & - & - & $<0.001$ & - & - & $\begin{array}{l}<0.001 \\
\tilde{0} .008\end{array}$ \\
\hline
\end{tabular}


Table 2

Isotopic composition of water samples taken in the Changzhi Basin.

\begin{tabular}{|c|c|c|c|c|c|c|c|c|c|c|c|c|c|c|c|}
\hline & \multicolumn{3}{|c|}{ shallow groundwater } & \multicolumn{3}{|c|}{ deep groundwater } & \multicolumn{3}{|c|}{ surface water } & \multicolumn{3}{|c|}{ rain water } & \multicolumn{3}{|c|}{ mine drainage } \\
\hline & Min & Max & Mean & Min & Max & Mean & Min & Max & Mean & Min & Max & Mean & Min & Max & Mean \\
\hline$\delta^{2} \mathrm{H}(\% \circ)$ & -76 & -51 & -66 & -74 & -53 & -68 & -63 & -46 & -52 & -104 & -11 & -45 & -84 & -59 & -73 \\
\hline$\delta^{18} \mathrm{O}(\%)$ & -10.1 & -6.3 & -8.9 & -9.9 & -6.5 & -9.1 & -8.3 & -5.2 & -6.3 & -14.1 & -2.0 & -6.9 & -11.4 & -7.9 & -9.8 \\
\hline
\end{tabular}

\section{2. $\delta^{18} \mathrm{O}$ and $\delta^{2} \mathrm{H}$ characteristics and groundwater provenance}

Stable water isotopes of hydrogen $\left(\delta^{2} \mathrm{H}\right)$ and oxygen $\left(\delta^{18} \mathrm{O}\right)$ are increasingly being applied as a useful tool for integrating information about hydrological processes across various scales (McDonnell and Beven, 2014; Li et al, 2019). Table 2 summarizes the isotopic composition of water samples taken in the Changzhi Basin.

\subsubsection{Rain water, surface water, and mine drainage}

The $\delta^{18} \mathrm{O}$ and $\delta^{2} \mathrm{H}$ of rain water, surface water, and mine drainage are plotted in Fig. 4a. The slope of the local meteoric water line (LMWL, $\left.\mathrm{k}=8.12\right)$ is similar to the global meteoric water line (GMWL, $\mathrm{k}=8.0$ ), and that the compositions of the stable hydrogen and oxygen isotopes are also aligned with the GMWL. The $\delta^{18} \mathrm{O}$ and $\delta^{2} \mathrm{H}$ compositions of rain water range from $-14.1 \%$ to $-2.0 \%$ ond $-104 \%$ o to $-11 \%$ o, respectively, surface water ranges from $-8.3 \%$ o to $-5.2 \%$ o and $-63 \%$ o to $-46 \%$, respectively, while mine drainage samples range from $-11.4 \%$ o to $-7.9 \%$ ond $-84 \%$ o to $-59 \%$, respectively (Table 2 ).

The surface water and mine drainage samples lie below the LMWL. When compared with the LMWL, the surface water and mine drainage isotopes can be seen to be enriched in heavy isotopes, and are located near the LMWL. This indicates that the surface water and mine drainage are recharged by rain water and have undergone evaporation and condensation, especially in the case of surface water. The mine drainage samples are scattered in the study area and thus could represent different recharge sources (Qian et al., 2013).

\subsubsection{Groundwater}

The $\delta^{18} \mathrm{O}$ and $\delta^{2} \mathrm{H}$ of groundwater are plotted in Fig. $4 \mathrm{~b}$. The $\delta^{18} \mathrm{O}$ and $\delta^{2} \mathrm{H}$ compositions of groundwater are located near the LMWL, which indicates that the groundwater is mainly recharged by rain water. The slope of the shallow groundwater line $(k=6.19)$ is smaller than that of the deep groundwater line $(k=$ 6.41), which means that the groundwater has undergone evaporation during the recharge process, especially in the case of shallow groundwater.

The $\delta^{18} \mathrm{O}$ and $\delta^{2} \mathrm{H}$ values for shallow groundwater range from $-10.1 \%$ o to $-6.3 \%$ o and $-76 \%$ o to $-51 \%$, respectively, while for deep groundwater the corresponding values are $-9.9 \%$ o to $-6.5 \%$ ond $-74 \%$ o to $-53 \%$, respectively. Some shallow groundwater samples have relatively low stable isotope concentrations and some deep groundwater samples have relatively high concentrations. This may have resulted from the interaction between shallow and deep groundwater. The $\delta^{18} \mathrm{O}$ and $\delta^{2} \mathrm{H}$ values of some shallow groundwater samples are consistent with surface water, indicating an interaction between surface water and shallow groundwater. Because of the lateral recharge from fissure groundwater at the edge of the basin, the $\delta^{18} \mathrm{O}$ and $\delta^{2} \mathrm{H}$ compositions of shallow groundwater are relatively low.

\subsection{Hydrochemical evolution processes}

\subsubsection{Effects of precipitation, evaporation, and rock-type on hydrochemistry}

A qualitative analysis, using the Gibbs diagram (Gibbs, 1970), was carried out to identify the dominant processes affecting evolution. The Gibbs diagram depicts the relative dominance of precipitation, rock weathering, and evaporation in semi-arid and arid regions. The diagrams show the weight ratios of $\mathrm{Na}^{+} /\left(\mathrm{Na}^{+}+\mathrm{Ca}^{2+}\right)$ and $\mathrm{Cl}^{-} /\left(\mathrm{Cl}^{-}+\mathrm{HCO}_{3}{ }^{-}\right)$against TDS, as shown in Fig. 5 .

Figure $5 b$ shows that the ratios of $\mathrm{Na}^{+} /\left(\mathrm{Na}^{+}+\mathrm{Ca}^{2+}\right)$ are mostly less than 0.5 and that the TDS is mostly low to medium, which indicates that rock weathering is the dominant mechanism in the geochemical evolution of groundwater for both shallow and deep groundwater. The ratios of $\mathrm{Na}^{+} /\left(\mathrm{Na}^{+}+\mathrm{Ca}^{2+}\right)$, however, show a wide range of values without any obvious changes in TDS values. This suggests that cation exchange also plays an important role by increasing $\mathrm{Na}^{+}$and decreasing $\mathrm{Ca}^{2+}$ when geochemical evolution is dominated by rock-weathering processes (Liu et al., 2015; Li et al., 2019). This occurs because 2 mmol. $\mathrm{L}^{-1}$ of $\mathrm{Na}^{+}$is exchanged with $1 \mathrm{mmol} \cdot \mathrm{L}^{-1}$ of $\mathrm{Ca}^{2+}$ during the cation exchange, and the mass concentration of $2 \mathrm{mmol} \cdot \mathrm{L}^{-1}$ of $\mathrm{Na}^{+}\left(46 \mathrm{mg} \cdot \mathrm{L}^{-1}\right)$ is nearly equal to $1 \mathrm{mmol} \cdot \mathrm{L}^{-1}$ of $\mathrm{Ca}^{2+}\left(40 \mathrm{mg} \cdot \mathrm{L}^{-1}\right)$. Some samples of shallow groundwater, however, are located on the upper right of the Gibbs diagram (Fig. $5 \mathrm{a}$ ), and the ratios of $\mathrm{Cl}^{-} /\left(\mathrm{Cl}^{-}+\mathrm{HCO}_{3}{ }^{-}\right)$are greater than 0.5 and the TDS value greater than $1,100 \mathrm{mg} \cdot \mathrm{L}^{-1}$. This shows that the groundwater chemistry is controlled not only by rock weathering, but also by evaporation (Xing et al., 2013).

\subsubsection{Effects of evaporation on groundwater salinity based on stable isotope}

The deuterium excess, as one of the most important indicators characterizing atmospheric precipitation for comprehensive environmental factors, is capable of quantifying the contribution of evaporation to groundwater salinity (Dansgaard, 1964; Li et al., 2019; Huang and Pang, 2012). In the study area, $\delta^{2} \mathrm{H}_{0}$ and $\delta^{18} \mathrm{O}_{0}$ were calculated for $-45 \%$ and $-6.9 \%$ of local mean rain water, although the $\delta^{2} \mathrm{H}_{0}$ and $\delta^{18} \mathrm{O}_{0}$ values do not affect the mineral dissolution to total salinity relationship; $S_{0}$, the total salinity of mean rain water, was defined as $0.035 \mathrm{~g} \cdot \mathrm{L}^{-1}$; $f$ is the remaining fraction of the reservoir; the average temperature 
of the groundwater was $14^{\circ} \mathrm{C}$ and the humidity was about $60 \%$. Thus, the relationship between $d$ and $f$ can be established as given in Eq. (1) (Huang and Pang, 2012).

$$
\begin{gathered}
d=\delta^{2} H-8 \delta^{18} O=\left(\delta^{2} H_{0}+1000\right) f^{\left(\alpha^{2} H_{0}-1\right)}-8\left(\delta^{18} O_{0}+1000\right) f^{\left(\alpha^{18} O_{0}-1\right)}+7000 \\
=955 \times f^{-0.08676}-8 \times 993.1 \times f^{-0.01546}+7000(1)
\end{gathered}
$$

$\frac{S_{0}}{f}-S_{0}$ was the salinity caused by direct evaporation; D was the salinity increased by mineral dissolution, and $D=S-S_{0}-\left(\frac{S_{0}}{f}-S_{0}\right)($ Huang and Pang, 2012).

As shown in Fig. 6a, the average total $d$-excess and TDS for shallow groundwater and deep groundwater are $4.63 \%$ and $744.02 \mathrm{mg} \cdot \mathrm{L}^{-1}, 4.72 \%$ and 510.86 $\mathrm{mg} \cdot \mathrm{L}^{-1}$, respectively. The contribution ratios of mineral dissolution in shallow groundwater and deep groundwater are $81-98 \%$ and $84-98 \%$, while the contribution ratio of evaporation is $0.2-4.7 \%$ and $0-2.4 \%$. In the study area, most groundwater depths are greater than $5 \mathrm{~m}$, and the groundwater is mainly recharged by rain water and bedrock fissure water, which favors the dissolution of minerals. Most of the water samples indicate no evaporation effects regardless of shallow groundwater or deep groundwater. Figure $6 \mathrm{~b}$ and $6 \mathrm{c}$ show that there is an almost exponential positive correlation between TDS and the contribution of mineral dissolution, and an almost exponential negative correlation between TDS and the contribution of evaporation, which indicates that mineral dissolution is the main contributor to the total salinity of groundwater.

\subsubsection{Effects of geochemical processes on hydrochemistry}

The relationship between $\left(\mathrm{Ca}^{2+}+\mathrm{Mg}^{2+}\right)$ and $\left(\mathrm{HCO}_{3}{ }^{-}+\mathrm{SO}_{4}{ }^{2-}\right)$ concentrations in groundwater samples is close to the carbonate and gypsum dissolution line (1:1 relationship line) if these ions are controlled by carbonate and gypsum equilibrium (Wang et al., 2006; Zhang et al., 2015). lon exchange (Ca ${ }^{2+}$ and $\mathrm{Mg}^{2+}$

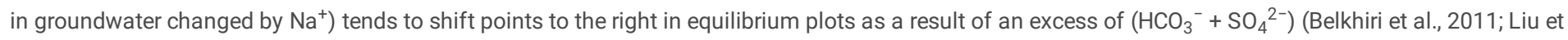
al., 2015), but reverse ion exchange shifts the points to the left as a result of an excess of $\left(\mathrm{Ca}^{2+}+\mathrm{Mg}^{2+}\right)$. As shown in Fig. 7a, values for most of the deep groundwater samples plot near the 1:1 line, which indicates that the dissolution of carbonate and gypsum is the main geochemical process in deep groundwater. Values for most of shallow groundwater samples are, however, scattered and located above the 1:1 line. This suggests that ion exchange is one of the main geochemical processes occurring in shallow groundwater in addition to the dissolution of carbonate and gypsum.

As shown in Fig. 7b, in the shallow groundwater, the $\mathrm{Na}^{+} / \mathrm{Cl}^{-}$mole ratio varies from 0.37 to 13.27 , with an average value of 2.07 . In the deep groundwater, the ratio ranges from 0.18 to 7.24 , with an average value of 1.21 . Most of the values for the deep groundwater samples are located near the 1:1 line, which suggests that the dissolution of halite is the major source of $\mathrm{Na}^{+}$and $\mathrm{Cl}^{-}$for deep groundwater. In contrast, most of the shallow groundwater values are scattered and are located below the 1:1 line. This indicates that there are other geochemical processes than halite dissolution leading to an excess of $\mathrm{Cl}^{-}$, such as $\mathrm{Ca}(\mathrm{Mg}) / \mathrm{Na}$ ion exchange.

Ion exchange and adsorption are common reactions in the geochemical evolution of groundwater and influence the major ion composition of groundwater ( $\mathrm{Li}$ et al., 2019). Schoeller (1967) proposed the chloral-alkali index (CAl) to analyze cation exchange and adsorption (Eqs. (2) and (3)).

$$
\begin{gathered}
C A I 1=\frac{C l^{-}-\left(N a^{+}+K^{+}\right)}{C l^{-}}(2) \\
C A I 2=\frac{C l^{-}-\left(N a^{+}+K^{+}\right)}{S O_{4}^{2-}+H C O_{3}^{-}+C O_{3}^{2-}+N O_{3}^{-}}(3)
\end{gathered}
$$

A positive CAl indicates the exchange of $\mathrm{Ca}^{2+}$ and $\mathrm{Mg}^{2+}$ from the rocks with $\mathrm{Na}^{+}$of the water, while a negative CAl indicates the exchange of $\mathrm{Na}^{+}$from the rocks with $\mathrm{Ca}^{2+}$ and $\mathrm{Mg}^{2+}$ of the water. Additionally, a diagram of $\left[\left(\mathrm{Ca}^{2+}+\mathrm{Mg}^{2+}\right)-\left(\mathrm{HCO}_{3}{ }^{-}+\mathrm{SO}_{4}{ }^{2-}\right)\right]$ versus $\left(\mathrm{Na}^{+}-\mathrm{Cl}^{-}\right)$(Eq. (4)) is also commonly used to explain cation exchange in groundwater (Carol et al., 2013; Huang et al., 2013; Liu et al., 2015). The diagram reflects excess $\mathrm{Ca}^{2+}$ and $\mathrm{Mg}^{2+}$ gained or lost from calcite, dolomite, and gypsum dissolution or precipitation, and excess $\mathrm{Na}^{+}$gained or lost from $\mathrm{NaCl}$ (Farid et al., 2013). If cation exchange plays a major role in controlling the major ion composition of groundwater, there will be a linear relationship with a slope close to - 1.0, as expressed by Eq. (4).

$$
N=\frac{\left(N a^{+}+K^{+}\right)-C l^{-}}{C a^{2+}+M g^{2+}-\left(H C O_{3}^{-}+S O_{4}^{2-}\right)}(4)
$$

Figure 8a shows that both positive and negative ion exchange occurs in groundwater. For shallow groundwater, the positive ion exchange was slightly dominant, and accounted for $51.3 \%$ of the ion exchange. This process mainly occurred at the central of the Changzhi Basin, which have a slower runoff and more shallow groundwater compared with the edge of the basin, leads to the large $\mathrm{Na}^{+}$content in the water displaced part of $\mathrm{Ca}^{2+}$ in the aquifer. In the edge part of the basin, the cations in the groundwater are dominated by $\mathrm{Ca}^{2+}$ and $\mathrm{Mg}^{2+}$. The groundwater passes through rocks that contain Na-rich minerals, which leads to exchange reactions and increased $\mathrm{Na}^{+}$in groundwater. For deep groundwater, the negative ion exchange process dominates, and accounts for $66.7 \%$ of the ion exchange. This process mainly occurs in the edge part of the basin, and is consistent with the shallow groundwater processes. The CAl 1 and CAI 2 of shallow groundwater ranged from -6.3 to 0.81 and -0.24 to 0.76 , respectively, while the CAl1 and CAI2 of deep groundwater ranged from - 12.4 to 0.62 and -0.31 to 0.22 , respectively. This suggested that the intensity of the cation exchange is different for the shallow and deep groundwater. 
The slope and correlation coefficients of the equations for the shallow and deep groundwater (Fig. 8b) are $-1.88\left(R^{2}=0.86\right)$ and $-0.34\left(R^{2}=0.88\right)$, indicating that $\mathrm{Ca}^{2+}, \mathrm{Mg}^{2+}$, and $\mathrm{Na}^{+}$participate in ion exchange. However, significant differences were observed between the theoretical and actual values, implying that cation exchange is not the sole process affecting the concentration of the three ions. The other processes affecting the ion content include the discharge of mine drainage, and the interaction between groundwater and surface water. These processes affect ion content because of the high $\mathrm{Na}^{+}$content of mine drainage and surface water (Table 1).

To better understand the hydrogeochemical processes in the aquifers, PHREEQC (Parkhurst and Appelo, 1999) was used to calculate the saturation indices of the major minerals. The saturation indices of minerals varied between -0.5 and +0.5 , which indicates that groundwater is saturated (or in equilibrium) or near saturation with respect to these minerals. As shown in Fig. 9a and b, most of the groundwater samples are in a state of saturation or over-saturation with respect to calcite and dolomite. Almost all the groundwater samples are in a state of under-saturation with respect to gypsum and are highly unsaturated in terms of halite (Fig. 9c and d). Precipitation is the main source of groundwater in the study area. During the percolation of weakly acidic rain, carbonate minerals dissolve quickly and it is easy for groundwater to reach a dissolution equilibrium with calcite and dolomite. No significant correlation is observed between TDS and the SI values of calcite and dolomite. SI values of gypsum and halite, however, tend to increase with TDS, which indicates that the dissolution of gypsum and halite is one of the main processes involved in the increase in groundwater salinity.

\subsection{Effects of anthropogenic activities on hydrochemistry}

The Changzhi Basin has a long history of agricultural development, and the main crops grown are corn and wheat. Furthermore, the Changzhi Basin is located in southeastern Shanxi Province, near the location of the Jindong coal-based industries. Human activities associated with these socio-economic developments impose extensive impacts on the groundwater environment. These impacts stem from the use of fertilizers in the agricultural areas, water drainage during coal mining, and sewage discharge from urban areas.

Groundwater pollution caused by anthropogenic activities is a world-wide issue (Li et al., 2019). According to the monitoring results from 195 cities in China, $97 \%$ of urban groundwater has been polluted (Zhang, 2015). From Table 1, the following are observed of the $\mathrm{NO}_{3}{ }^{-}$concentrations:

- 22 of the shallow groundwater samples exceed the limits of the level III quality standards for groundwater $\left(20 \mathrm{mg} \cdot \mathrm{L}^{-1}\right.$ as $\left.\mathrm{NO}_{3}-\mathrm{N}\right)$, and have a mean value of $55.3 \mathrm{mg} \cdot \mathrm{L}^{-1}$.

- 18 of the shallow groundwater samples exceed the limits of the level IV quality standards for groundwater $\left(30 \mathrm{mg} \cdot \mathrm{L}^{-1}\right.$ as $\left.\mathrm{NO}_{3}-\mathrm{N}\right)$ and have a mean value of $65.68 \mathrm{mg} \cdot \mathrm{L}^{-1}$.

- Seven of the deep groundwater samples exceed the limits of the level III quality standards for groundwater and have a mean value of $47.44 \mathrm{mg} \cdot \mathrm{L}^{-1}$.

- Three of the deep groundwater samples exceed the limits of the level IV quality standards for groundwater, and have a mean value of $76.28 \mathrm{mg} \cdot \mathrm{L}^{-1}$.

Thus, $\mathrm{NO}_{3}-\mathrm{N}$ pollution in the shallow groundwater is more serious than that in the deep groundwater, and mainly occurs in the central and northeastern agricultural areas, and in the urban area in the east of the basin. The main sources of $\mathrm{NO}_{3}-\mathrm{N}$ exceedance are fertilizer application and the discharge of human waste and sewage. The average nitrogen fertilizer application rate per ha of cultivated land is approximately $832.81 \mathrm{~kg}$, which is far in excess of the average rate for China (339 kg/ha) (Chen et al., 2016).

Mine drainage during coal mining is also a cause for concern because of the relatively high $\mathrm{Na}^{+}, \mathrm{Cl}^{-}, \mathrm{SO}_{4}{ }^{2-}, \mathrm{HCO}_{3}{ }^{-}$, and TDS concentrations. When compared with the combined average values for shallow groundwater, deep groundwater, and surface water, the mine water has the following characteristics:

- Mean $\mathrm{Na}^{+}$content of mine drainage was 7.69-23.87 times that of the combined average.

- Mean $\mathrm{Cl}^{-}$content was 3.36-7.56 times the average.

- Mean $\mathrm{SO}_{4}{ }^{2-}$ content was 1.86-2.97 times the average.

- Mean $\mathrm{HCO}_{3}{ }^{-}$content was 2.25-3.29 times the average.

- Mean TDS content was 2.16-3.15 times the average.

The amount of mine drainage was 0.39 million $\mathrm{m}^{3} \cdot \mathrm{d}^{-1}$ in the Changzhi mining area, and was directly discharged into surface water, which interacts with groundwater, especially shallow groundwater, thus leading to an increase in $\mathrm{Na}^{+}, \mathrm{Cl}^{-}, \mathrm{SO}_{4}{ }^{2-}$, and $\mathrm{HCO}_{3}{ }^{-}$content of groundwater.

\section{Conclusions}

In this study, the integrated approach consisting of Piper diagram, stable isotopes, Gibbs diagrams and ionic ratios provided an efficient way for analyzing the groundwater origin and hydrochemical processes that affected water chemistry. The Piper diagram and coefficient of variation were used to characterize the groundwater hydrochemistry and the stability of ions content; stable isotopes was a useful tool for analysis the origin and transformation of groundwater; Gibbs diagrams were used to establish the dominant effects of precipitation, rock weathering, or evaporation on geochemical evolution of groundwater, and deuterium excess was a capable way to quantify the contribution of evaporation to groundwater salinity; ionic ratios and saturation indices were used to depict the effects of mineral dissolution or precipitation on groundwater salinity. These methods were complementary of and verify each other. The main conclusions drawn are summarized as follows:

The groundwater chemistry type of both shallow and deep groundwater demonstrates zonational characteristics from the west to east of the basin; the TDS content gradually increases (from 208.8 to $2,559 \mathrm{mg} \cdot \mathrm{L}^{-1}$ ) and the types of hydrochemistry tend to be complex. In both shallow and deep groundwater, the 
hydrochemistry types are mainly $\mathrm{HCO}_{3}-\mathrm{Ca}$ and $\mathrm{HCO}_{3} \cdot \mathrm{SO}_{4}-\mathrm{Ca} \cdot \mathrm{Mg}$. The stable isotope compositions suggest that rain water is main recharge source for both shallow and deep groundwater. The interactions between shallow and deep groundwater, surface water and shallow groundwater and the lateral recharge from fissure groundwater at the edge of the basin have affected the isotopic composition of groundwater.

The hydrochemical and isotopic interpretation showed that the hydrochemical composition of the groundwater was controlled by geochemical processes. Gibbs diagrams suggested that water-rock interaction was the main mechanism controlling groundwater chemistry. The deuterium excess method revealed that that mineral dissolution accounts for $81-98 \%$ of the salinity of shallow groundwater and $84-98 \%$ of deep groundwater. The dissolution of gypsum and halite makes a significant contribution to the increase of groundwater salinity. Overall, rock weathering in conjunction with the cation exchange absolutely predominated in the geochemical evolution of groundwater.

The hydrochemical composition of groundwater in the study area is also affected by anthropogenic activities. $\mathrm{NO}_{3}-\mathrm{N}$ pollution occurs in the central area, the northeastern agricultural area, and the urban area in the east of the basin, and is more serious for shallow groundwater than for deep groundwater. The main sources of $\mathrm{NO}_{3}-\mathrm{N}$ are fertilizer application, human waste, and sewage. Mine drainage has relatively high concentrations of $\mathrm{Na}^{+}, \mathrm{Cl}^{-}, \mathrm{SO}_{4}{ }^{2-}, \mathrm{HCO}_{3}{ }^{-}$, and $\mathrm{TDS}^{-}$ when compared with shallow groundwater, deep groundwater, and surface water. Mine drainage is directly discharged into surface water and consequently interacts with groundwater, thus leading to an increase of $\mathrm{Na}^{+}, \mathrm{Cl}^{-}, \mathrm{SO}_{4}{ }^{2-}$, and $\mathrm{HCO}_{3}{ }^{-}$content of groundwater. The results of the present study provide a deeper insight into the water quality situation and geochemical evolution of groundwater, and will assist decision-makers to formulate sustainable groundwater management strategies for the study area.

\section{Declarations Conflicts of interest}

The authors declare no conflicts of interest.

\section{Acknowledgments}

This work was supported by the Fundamental Research Funds for the Chinese Academy of Geosciences (No. JYYWF20180401) and the China Geological Survey project (No. DD20160296, DD20201123). We thank Paul Seward, PhD, from Liwen Bianji, Edanz Editing China (www.liwenbianji.cn/ac), for editing the English text of a draft of this manuscript.

\section{References}

1. Appelo C, Postma D (2004) Geochemistry, Groundwater and Pollution

2. Belkhiri L, Boudoukha A, Mouni L et al (2011) Statistical categorization geochemical modeling of groundwater in Ain Azel plain (Algeria). Journal of African Earth Science 59:140-148

3. Carol E, Mas-Pla J, Kruse E (2013) Interaction between continental and estuarine waters in the wetlands of the northern coastal plain of Samborombón Bay, Argentina. Applied Geochemistry 34:152-163

4. Chang J, Wang G (2010) Major ions chemistry of groundwater in the arid region of Zhangye Basin, northwestern China. Environmental Earth Science 61:539-548

5. Chen J, Wu H, Qian H (2016) Groundwater nitrate contamination and associated health risk for the rural communities in an agricultural area of Ningxia, northwest China. Expo Health 8:1-11

6. Chen J, Liu X, Wang C et al (2012) Isotopic constraints on the origin of groundwater in the Ordos Basin of northern China. Environmental Earth Science 66:505-517

7. Chen L, Zhang Y, Wang C (2012) A study of evolution of the discharge of the Xin'an spring with time series analysis. Hydrogeology Engineering Geology 39:19-23 (in Chinese)

8. Clark I, Fritz P (1997) Environmental Isotopes in Hydrogeology. Lewis Publishers, New York

9. Cook P, Herczeg A (1999) Environmental traces in subsurface hydrology. Kluwer, Dordrecht

10. Dansgaard W (1964) Stable isotopes in precipitation. Tellus 16:436-468

11. Farid I, Trabelsi R, Zouari K et al (2013) Hydrogeochemical processes affecting groundwater in an irrigated land in Central Tunisia. Environmental Earth Science 68:1215-1231

12. Gibbs R (1970) Mechanisms controlling world water chemistry. Science 170:1088-1090

13. Huang G, Sun J, Zhang Y et al (2013) Impact of anthropogenic and natural processes on the evolution of groundwater chemistry in a rapidly urbanized coastal area, South China. Sci Total Environ 463-464:209-221

14. Huang T, Pang Z (2012) The role of deuterium excess in determining the water salinisation mechanism: a case study of the arid Tarim River Basin, NW China. Applied Geochemistry 27:2382-2388

15. Jamshidzadeh Z, Mirbagheri S (2011) Evaluation of groundwater quantity and quality in the Kashan Basin, Central Iran. Desalination 270:23-30

16. Jia Y, Guo H, Xi B et al (2017) Sources of groundwater salinity and potential impact on arsenic mobility in the western Hetao Basin, Inner Mongolia. Sci Total Environ 601-602:691-702 
17. Li Z, Yang Q, Yang Y et al (2019) Isotopic and geochemical interpretation of groundwater under the influences of anthropogenic activities. Journal of Hydrology 576:685-697

18. Li Z, Wang G, Wang X et al (2018) Groundwater quality and associated hydrogeochemical processes in Northwest Namibia. Journal of Geochemical Exploration 186:202-214

19. Liu F, Song X, Yang L et al (2015) The role of anthropogenic and natural factors in shaping the geochemical evolution of groundwater in the Subei Lake basin, Ordos energy base, Northwestern China. Science of the Total Environment 538:327-340

20. Marfia A, Krishnamurthy R, Atekwana E et al (2004) Isotopic and geochemical evolution of ground and river waters in a karst dominated geological setting: a case study from Belize, Central America. Applied Geochemistry 19:937-946

21. McDonnell J, Beven K (2014) Debates-The future of hydrological sciences: a (common) path forward? A call to action aimed at understanding velocities, celerities and residence time distributions of the headwater hydrograph. Water Resource Research 50:5342-5350

22. Mohanty A, Rao V et al (2019) Hydrogeochemical, seawater intrusion and oxygen isotope studies on a coastal region in the Puri District of Odisha, India. Catena 172:558-571

23. Parkhurst D, Appelo C (1999) User's guide to PHREEQC - a computer program for speciation, reaction-path, 1D-transport, and inverse geochemical calculation. US Geological Survey Water Resources Investigations Report. 99-4259

24. Plummer L, Busby J, Lee R et al (1990) Geochemical modeling of the Madison aquifer in parts of Montana, Wyoming, and South Dakota. Water Resour Res 26:1981-2014

25. Qian H, Li P, Wu J (2013) Isotopic characteristics of precipitation, surface and groundwater in the Yinchuan plain, Northwest China. Environmental Earth Science 70:57-70

26. Sánchez D, Barberá J, Mudarra M (2015) Hydrogeochemical tools applied to the study of carbonate aquifers: examples from some karst systems of Southern Spain. Environmental Earth Science 74:199-215

27. Sandow M, Bruce B, Thomas M (2010) Analysis of groundwater quality using multivariate and spatial analyses in the Keta basin, Ghana. Journal of African Earth Sciences 58:220-234

28. Schoeller H (1967) Geochemistry of Groundwater- an International Guide for Research and Practice

29. Selvakumar S, Chandrasekar N, Kumar G (2017) Hydrogeochemical characteristics and groundwater contamination in the rapid urban development areas of Coimbatore, India. Water Resource Industry 17:26-33

30. Skrzypek G, Dogramaci S, Grierson P (2013) Geochemical and hydrological processes controlling groundwater salinity of a large inland wetland of northwest Australia. Chemical Geology 357:164-177

31. Sun X (2008) The application of fuzzy judgement in karst groundwater quality of Xin'an spring region. Journal of Taiyuan University of Technology 39:418-421 (in Chinese)

32. Tizro T, Voudouris K (2008) Groundwater quality in the semi-arid region of the Chahardouly basin, West Iran. Hydrological Processes 22:3066-3078

33. Wang Y, Guo Q, Su C, Ma T (2006) Strontium isotope characterization and major ion geochemistry of karst water flow, Shentou, northern China. Journal of Hydrology 328:592-603

34. Xing LN et al (2013) Groundwater hydrochemical characteristics and processes along flow paths in the North China Plain. J Asian Earth Science 70$71: 250-264$

35. Yang Q, Li Z, Ma H et al (2016) Identification of the hydrogeochemical processes and assessment of groundwater quality using classic integrated geochemical methods in the Southeastern part of Ordos basin, China. Environmental Pollution 2:879-888

36. Yang R, Jin H, Hao X et al (2016) Assessment of karst groundwater vulnerability in Xin'an spring area based on modified RISKE model. Environmental Science Technology 39:170-174 (in Chinese)

37. Zang C, Dame J, Nüsser M (2018) Hydrochemical and environmental isotope analysis of groundwater and surface water in a dry mountain region in Northern Chile. Environ Monit Assess 190:334

38. Zhai Y, Zheng F, Zhao X et al (2019) Identification of hydrochemical genesis and screening of typical groundwater pollutants impacting human health: A case study in Northeast China. Environmental Pollution 252:1202-1215

39. Zhang C, Wang W, Sun Y et al (2015) Processes of hydrochemical evolution of groundwater in the Guanzhong basin, China. Journal of Groundwater Science Engineering 3:136-146

40. Zhang H (2015) Risk assessment on Non-point Nitrogen Pollution in groundwater. Jilin University

\section{Figures}

\section{Figure 1}

Location of the study area and sampling sites 


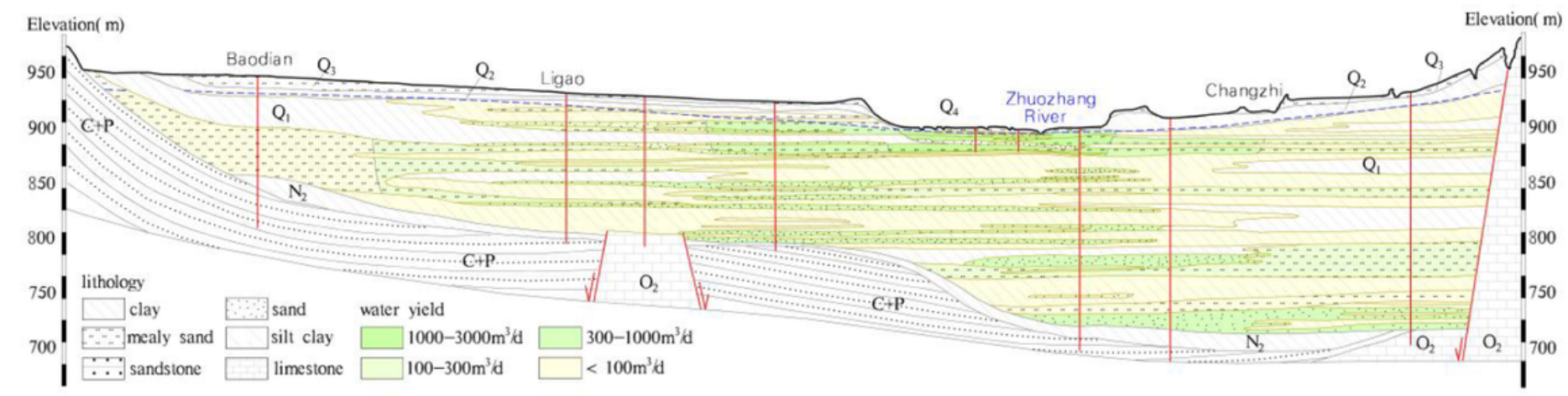

\section{Figure 2}

Hydrogeological cross-section (along line A-A' in Fig. 1) of the study area
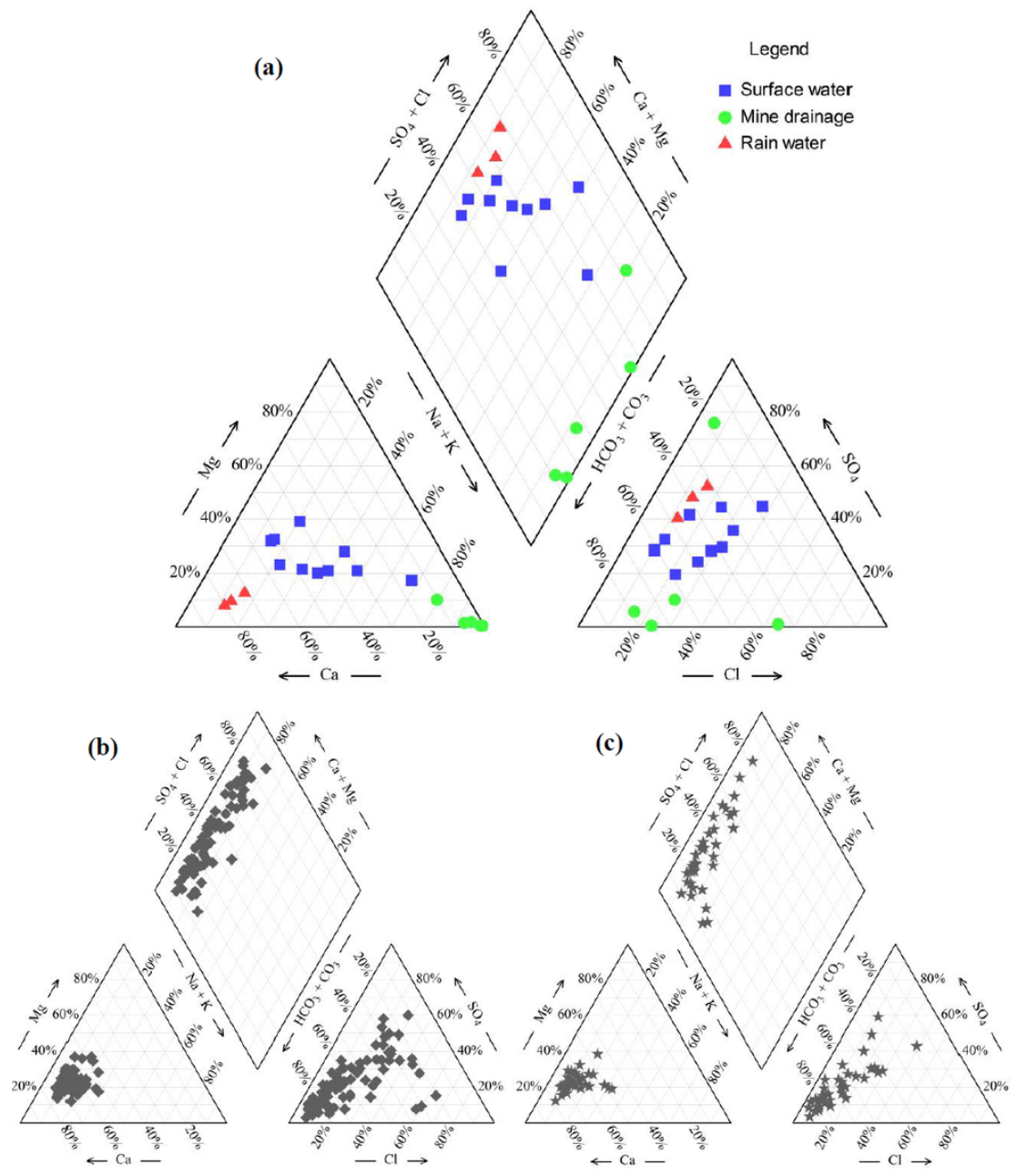

Figure 3

Piper diagrams of: (a) surface water, mine drainage, and rain water; (b) shallow groundwater; and (c) deep groundwater. 

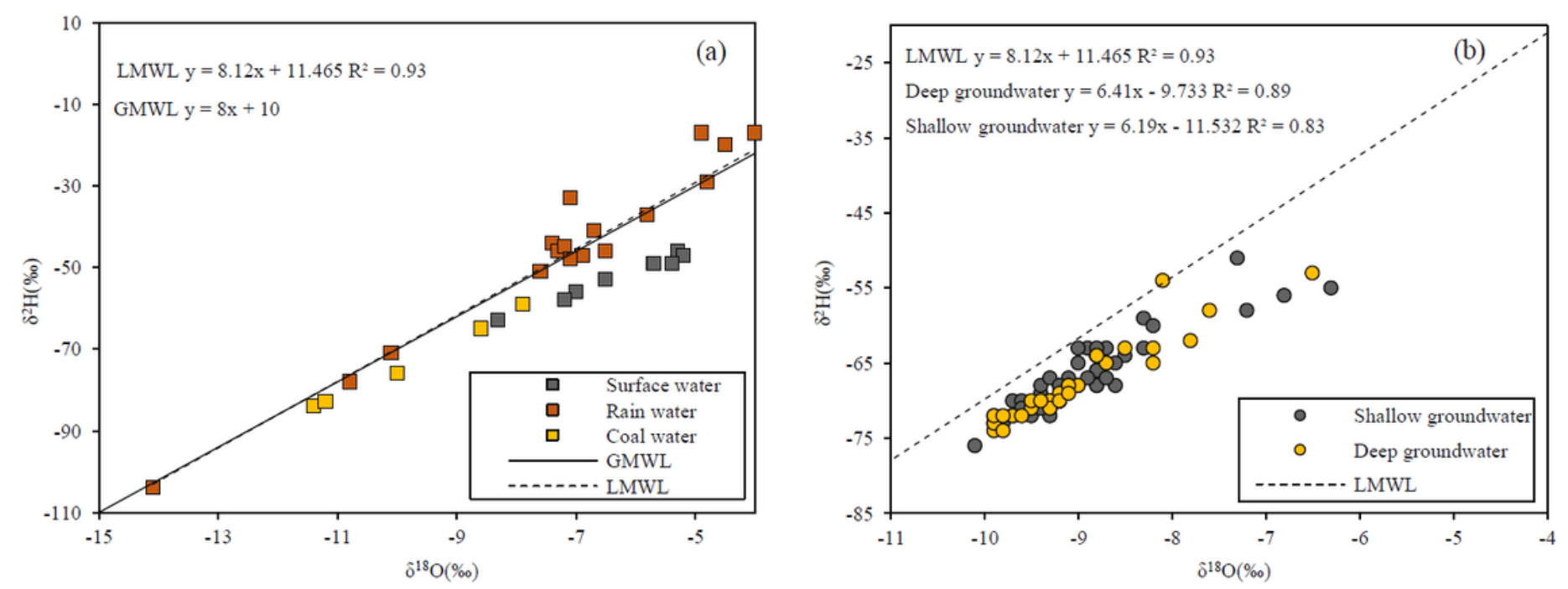

Figure 4

Plots of $\delta 180$ versus $\delta 2 \mathrm{H}$ for all water bodies
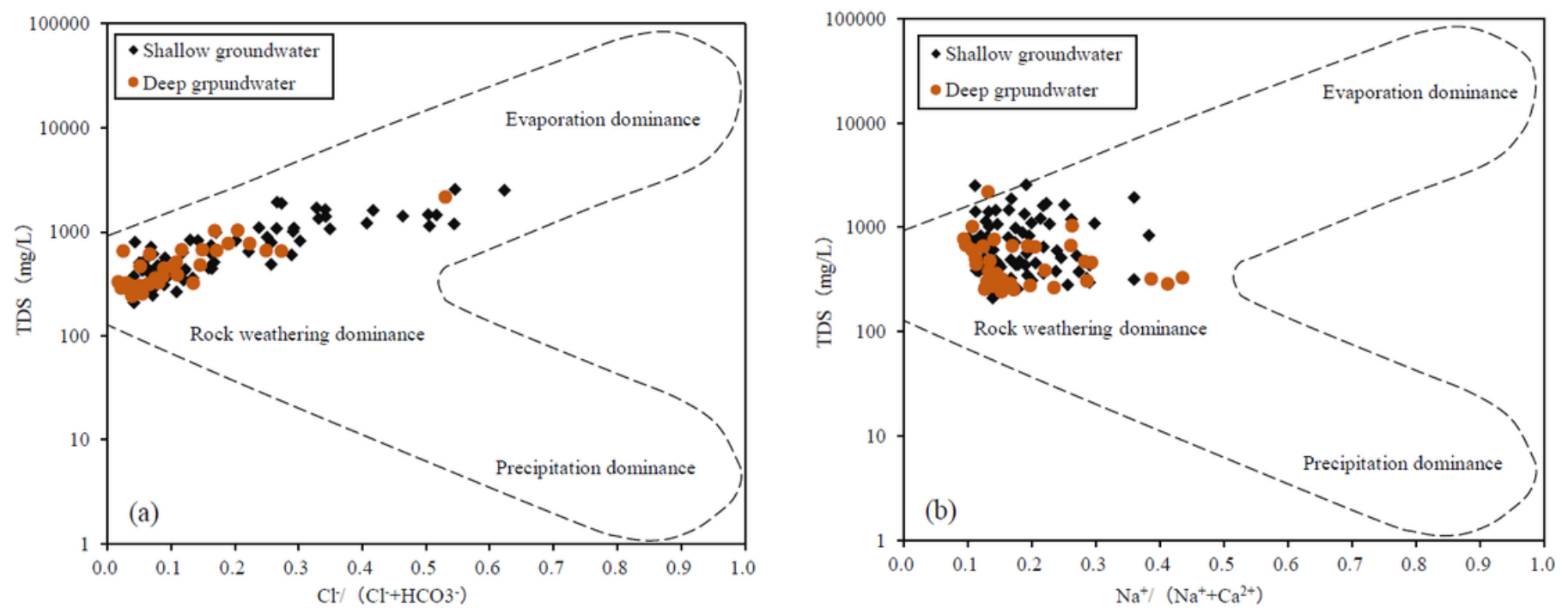

\section{Figure 5}

Gibbs diagrams of groundwater samples from the Changzhi Basin
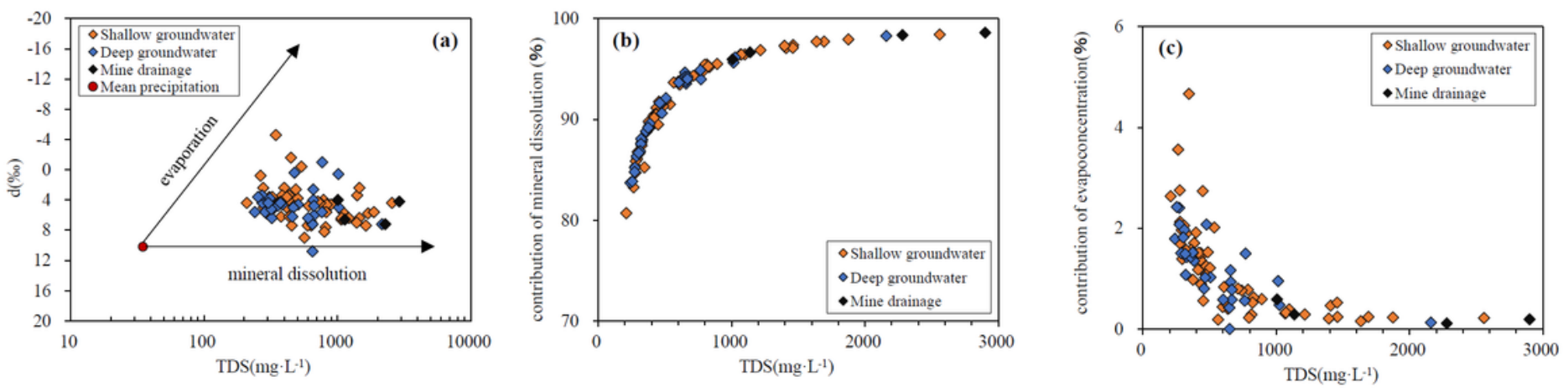

Figure 6

Relationship between TDS and (a) deuterium excess, (b) contribution of mineral dissolution, and (c) evaporation in the Changzhi Basin. 

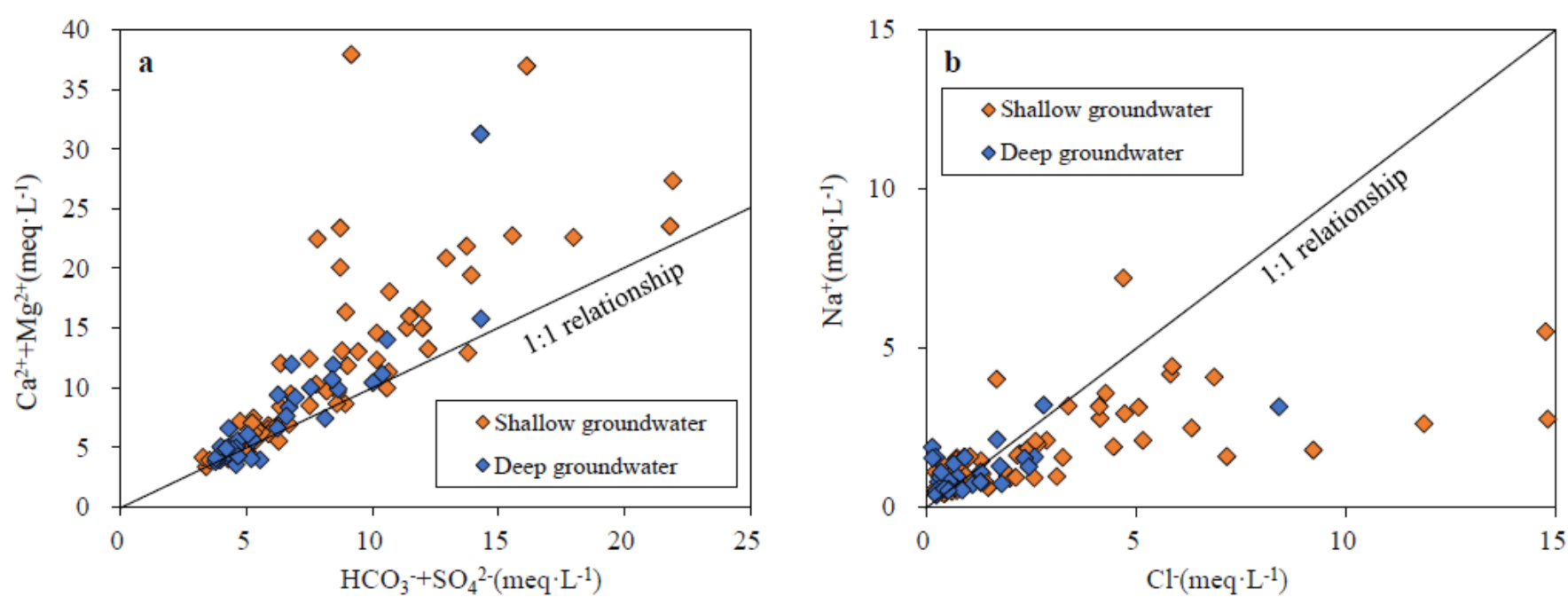

Figure 7

Plots of (a) (Ca2++Mg2+) vs. (HCO3- + SO42-), and (b) $\mathrm{Na}+$ vs. Cl- (b) (units are meq $\cdot \mathrm{L}-1$ )
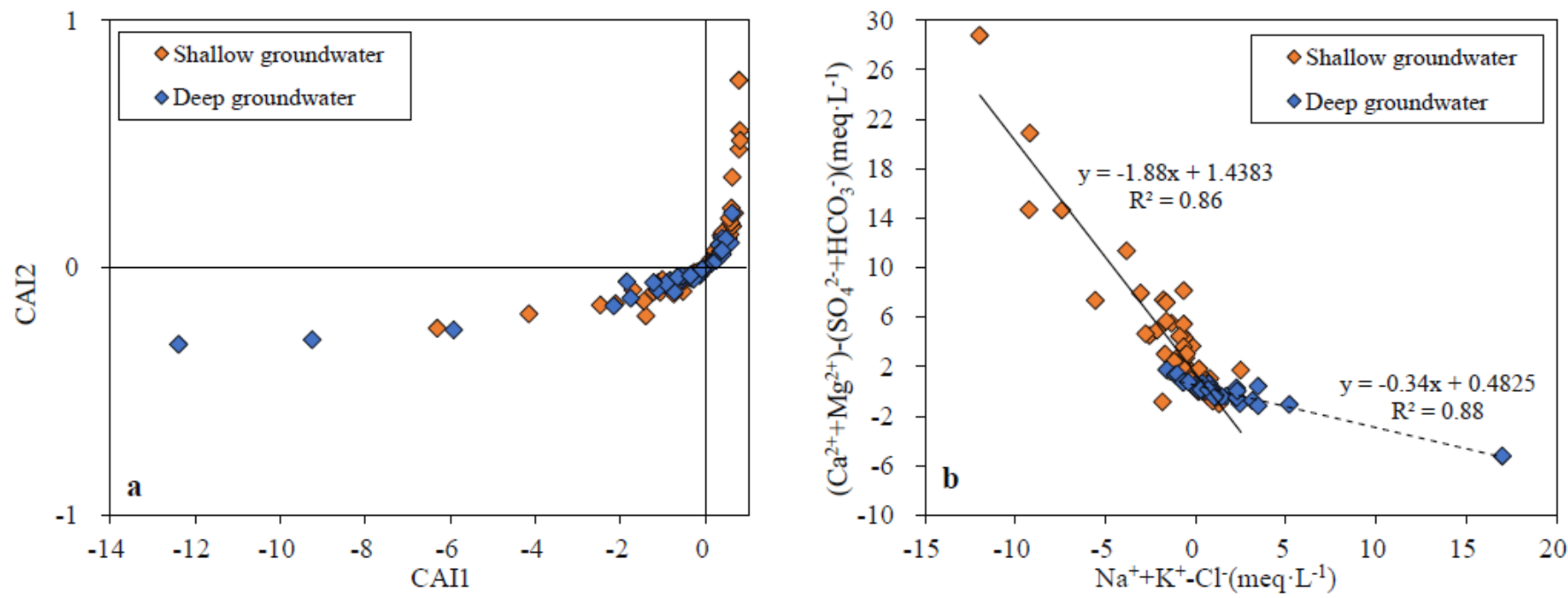

\section{Figure 8}

CAl1 vs. CAl2 (a) and (Ca2++Mg2+) - (HCO3-+SO42-) vs. (Na++K+-Cl-) (b) of groundwater 

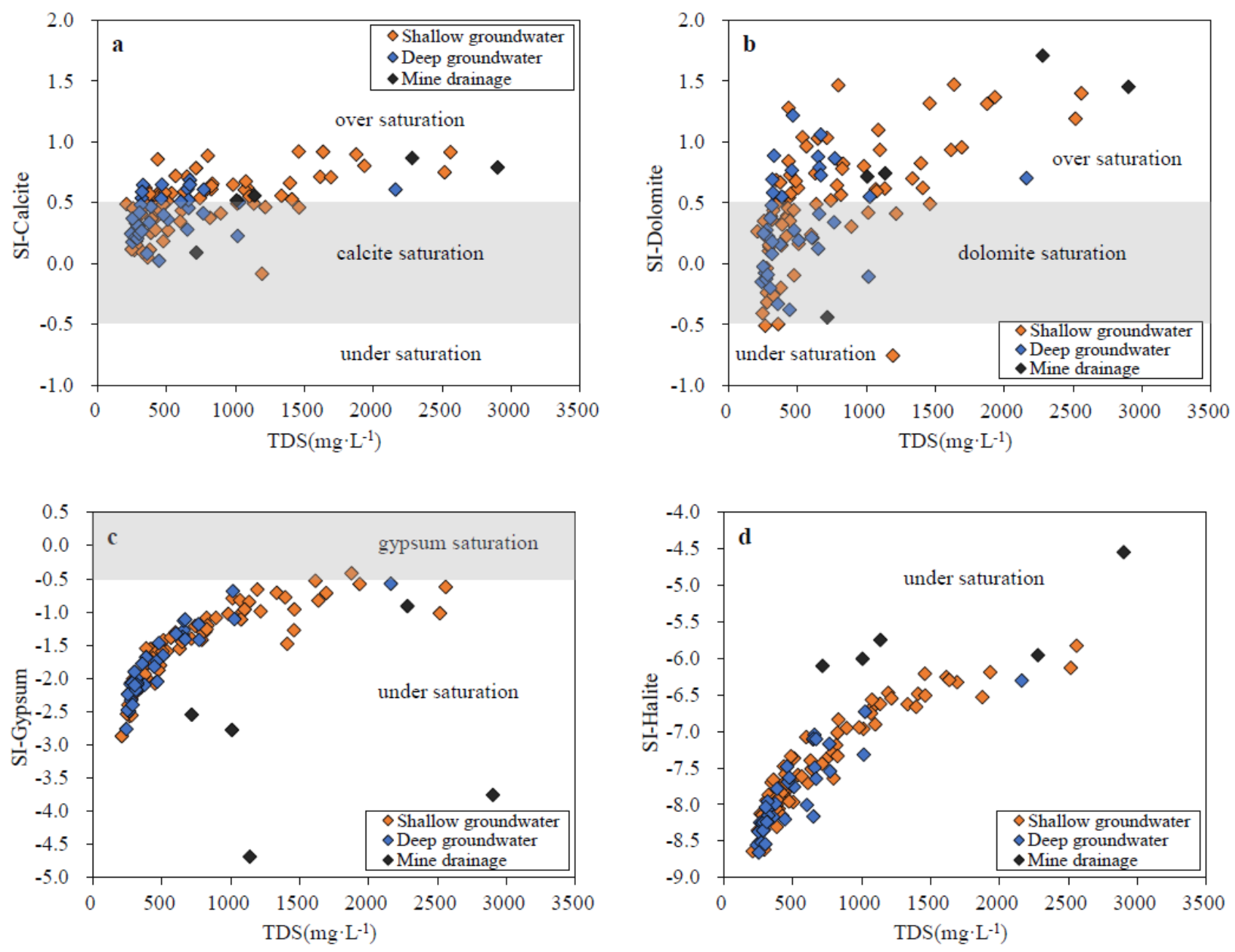

\section{Figure 9}

Saturation indices of groundwater samples vs. TDS: (a) calcite, (b) dolomite, (c) gypsum, (d) halite. 